\title{
Eugeniusz Brzuska*
}

Naczelna Organizacja Techniczna Oddział w Łodzi

\section{CHARAKTERYSTYKA POMOCY PUBLICZNEJ UDZIELANEJ SEKTOROWI MŚP ZE ŚRODKÓW UNIJNYCH PRZEZ URZĘDY PRACY - PRZYKŁAD ŁÓDZKICH URZĘDÓW PRACY}

\begin{abstract}
Streszczenie
Sektor MŚP jest niezwykle istotny dla polskiej gospodarki. W okresie programowym 2007-2013 została udzielona na rzecz polskich przedsiębiorstw, w tym także sektora MŚP, pomoc publiczna w znacznej wysokości, w tym w ramach funduszy unijnych. Pomoc tę przekazywały instytucje regionalne i krajowe, w tym także urzędy pracy. Od 2015 roku nastąpiły podsumowania przekazanej pomocy publicznej, z których wynika, że pomoc ta została przekazana lege artis, zgodnie z procedurą. Natomiast z przedstawionych podsumowań nie wynika stwierdzenie, czy pomoc ta przyniosła trwałe, długofalowe efekty dla przedsiębiorstw, którym została udzielona. W artykule przedstawiono definicję pomocy publicznej, jej rodzaje i wielkości jej udzielania, w tym przez urzędy pracy sektorowi MŚP ze środków unijnych. Natomiast problem efektywności jej udzielenia jest postawiony jako otwarte pytanie badawcze.
\end{abstract}

Słowa kluczowe: pomoc publiczna, fundusze unijne, instytucje publiczne, sektor MŚP

\footnotetext{
* Adres e-mail: ebrzuska@onet.pl.
} 


\section{Wprowadzenie}

Sektor MŚP jest dla polskiej gospodarki niezwykle istotny. Jest on jednym z kreatorów wzrostu gospodarczego, a także daje miejsca pracy olbrzymiej ilości pracowników. W okresie programowym 2007-2013 wsparcie udzielane z funduszy unijnych, które przybierało postać zgodną z definicją pomocy publicznej, w tym pomocy de minimis, było w dużej mierze kierowane do sektora MŚP, w tym także w ramach programów obsługiwanych przez urzędy pracy. Celem artykułu było ukazanie problematyki przekazywania środków spełniających kryterium pomocy publicznej, w tym w ramach urzędów pracy, dla sektora MŚP. Pomoc publiczna udzielona w tym okresie ukazywana jest jako przekazana w sposób zgodny ze wszystkimi procedurami oraz założeniami. Natomiast dokonując przeglądu badawczego dokumentów jej dotyczących, trudno wyciągnąć wnioski dotyczące ewentualnych bardziej długofalowych efektów związanych z udzieleniem tej pomocy. Dlatego też ciągle otwartym problemem badawczym pozostaje kwestia efektywności udzielanej pomocy publicznej, w tym w sektorze MŚP, przez urzędy pracy.

\section{Istota pomocy publicznej}

Pomoc publiczna została zdefiniowana w artykule 107 Traktatu o Unii Europejskiej. Nie precyzuje on w sposób szczegółowy, czym jest dokładnie pomoc publiczna, natomiast posługuje się określeniem, które możemy uznać za na tyle szerokie, iż istnieje duże pole do popisu dla wielu doprecyzowań i interpretacji, które mają miejsce na poziomie poszczególnych aktów prawnych, które są przez Unię wydawane a które dotyczą kwestii pomocy publicznej. Traktat w artykule 107 definiuje, iż „,wszelka pomoc przyznawana przez Państwo Członkowskie lub przy użyciu zasobów państwowych w jakiejkolwiek formie, która zakłóca lub grozi zakłóceniem konkurencji poprzez sprzyjanie niektórym przedsiębiorstwom lub produkcji niektórych towarów, jest niezgodna z rynkiem wewnętrznym w zakresie, w jakim wpływa na wymianę handlową między Państwami Członkowskimi”. Natomiast w dalszej części artykułu została sprecyzowana pomoc publiczna, która przez Unię Europejską jest uznawana za zgodną ze wspólnym rynkiem (Traktat o Unii Europejskiej, s. 47, dalej TFUE). 
Pomoc de minimis jest szczególnym rodzajem pomocy publicznej udzielanej przedsiębiorcom. Zgodnie z Rozporządzeniem Komisji (UE) nr 1407/2013 z dn. 18 grudnia 2013 roku w sprawie stosowania art. 107 i 108 TFUE, pomoc, której wartość dla danego beneficjenta w okresie trzech kolejnych lat podatkowych nie przekracza 200 tys. euro lub 100 tys. euro w sektorze transportu drogowego towarów, czyli tak zwana pomoc de minimis, nie wpływa na handel między państwami członkowskimi oraz nie zakłóca i nie zagraża zakłóceniem konkurencji, dlatego też nie podlega przepisom art. 107 ust. 1 TFUE. Jak wspomniano wyżej, jest ona udzielana zgodnie z Rozporządzeniem nr 1407/2013 Komisji Europejskiej i Rady (UE). W odniesieniu do tego rodzaju pomocy przyjmuje się, że nie zakłóca ona lub nie grozi zakłóceniem konkurencji oraz nie wpływa ona na wymianę handlową pomiędzy państwami członkowskimi UE (Instrukcja...).

\section{Pomoc publiczna udzielana w Polsce}

Procedury związane ze stosowaniem lub nie pomocy publicznej są przez Komisję Europejską traktowane bardzo poważnie, a kategoria ta jest niezwykle istotna dla funkcjonowania wspólnego rynku kategorią prawną. W Polsce podmiotami, które udzielają pomocy publicznej, są organy administracji publicznej, a także inne uprawnione do tego podmioty. Wymienia się tutaj w szczególności marszałków województw, prezydentów, burmistrzów i wójtów, w regionach także urzędy pracy, w skali kraju ministrów, prezesów agencji i agend państwowych (Raport o pomocy publicznej...).

Pomoc publiczna jest udzielana w postaci różnych form, zgodnie $\mathrm{z}$ nomenklaturą Komisji Europejskiej (oznaczone literami A, B, C i D oraz zaznaczone cyfrą 1 lub $2 \mathrm{w}$ zależności od tego, czy pomoc publiczna była przyznawana bezpośrednio z budżetu, czy też kosztem uszczuplenia wpływów budżetowych). Grupa A: dotacje i ulgi podatkowe, grupa B: subsydia kapitałowo-inwestycyjne, grupa $\mathrm{C}$ to tzw. miękkie kredytowanie, grupa $\mathrm{D}$ to poręczenia i gwarancje, natomiast grupa $\mathrm{E}$ to inne rodzaje udzielanej pomocy publicznej.

Ogólna wartość pomocy publicznej udzielonej przedsiębiorcom w Polsce w 2015 roku wyniosła 19,3576 mld zł, co stanowi 4,6267 mld euro. Natomiast ogólna wartość pomocy de minimis udzielonej przedsiębiorcom w 2015 roku wyniosła 4,8929 mld zł, co wyniosło 1,1695 mld euro $(0,27 \%$ PKB). Jak widać, są to wartości stosunkowo 
duże, mające swoje odzwierciedlenie w wielkości PKB kraju. Natomiast, porównawczo z poprzednim okresem, to jest szczególnie z okresem 2012-2014, odnotowuje się spadek udzielanej pomocy de minimis. W roku 2015, w porównaniu z 2014 rokiem, liczba beneficjentów pomocy de minimis była mniejsza o ok. 24 tys. Ponad 400 podmiotów mniej udzieliło tej pomocy a liczba przypadków jej udzielenia była o ponad 40 tys. mniejsza w porównaniu z rokiem poprzednim. W latach 2012-2014 obserwowany był znaczny wzrost wielkości udzielanej tego typu pomocy. W roku 2014 osiągnęła ona najwyższą w całym okresie jej udzielania wartość, czyli 6,6296 mld zł (Raport o pomocy de minimis).

W latach 2010-2012 wartość pomocy de minimis stanowiła średnio ok. 14-16\% całkowitej wartości pomocy udzielonej przedsiębiorcom. W latach 2013-2015 jej udział przekroczył już 20\%, głównie w wyniku znacznego wzrostu wartości pomocy de minimis w latach 2013-2015 w porównaniu z 2012 rokiem. Pomoc publiczna udzielana zgodnie z przesłankami art. 107 TFUE wykazywała w latach 2013-2015 duże fluktuacje jej wielkości. Pomoc de minimis była w tym okresie takich fluktuacji pozbawiona. Natomiast porównując udzielanie obu rodzajów pomocy w dłuższej perspektywie, tj. dla przykładu na przestrzeni lat 2010-2015, można zauważyć, iż tendencja zmian wartości pomocy publicznej była zbieżna $\mathrm{z}$ tendencją zmian pomocy de minimis. Przytoczone powyżej wielkości obrazuje tabela 1.

Tabela 1. Rodzaje pomocy publicznej porównawczo (w mln zł)

\begin{tabular}{|l|c|c|c|c|c|c|}
\hline $\begin{array}{c}\text { Rodzaj i wielkość udzielanej } \\
\text { pomocy w danym roku }\end{array}$ & 2010 & 2011 & 2012 & 2013 & 2014 & 2015 \\
\hline $\begin{array}{l}\text { Pomoc publiczna spełniająca } \\
\text { przesłanki art. 107 TFUE }\end{array}$ & $\begin{array}{c}24087,3 \\
(83,9 \%)\end{array}$ & $\begin{array}{c}21462,5 \\
(86,3 \%)\end{array}$ & $\begin{array}{c}21795,6 \\
(83,5 \%)\end{array}$ & $\begin{array}{c}22116,9 \\
(78,5 \%)\end{array}$ & $\begin{array}{c}26024,6 \\
(79,7 \%)\end{array}$ & $\begin{array}{c}19357,6 \\
(79,8 \%)\end{array}$ \\
\hline Pomoc de minimis & $\begin{array}{c}4618,6 \\
(16,1 \%)\end{array}$ & $\begin{array}{c}3418,6 \\
(13,7 \%)\end{array}$ & $\begin{array}{c}4315,6 \\
(16,5 \%)\end{array}$ & $\begin{array}{c}6068,8 \\
(21,5 \%)\end{array}$ & $\begin{array}{c}6629,6 \\
(20,3 \%)\end{array}$ & $\begin{array}{c}4892,9 \\
(20,2 \%)\end{array}$ \\
\hline
\end{tabular}

Źródło: Raport o pomocy de minimis w Polsce udzielonej przedsiębiorcom w 2015 r.

\section{Pomoc publiczna udzielana przez urzędy pracy}

W okresie programowym 2007-2013 urzędy pracy były jednymi z tych podmiotów, które udzielały bardzo znaczącej pomocy publicznej przedsiębiorcom. Pomoc ta była przekazywana w dużej mierze z Europejskiego Funduszu Społecznego w ra- 
mach Programu Operacyjnego Kapitał Ludzki (POKL) na lata 2007-2013. Urzędy pracy w całej Polsce w tym okresie przygotowywały i realizowały projekty, w ramach następujących Priorytetów i Działań Programu Operacyjnego Kapitał Ludzki:

- w ramach VI Priorytetu powyższego Programu Rynek otwarty dla wszystkich, w ramach Działania 6.1 Poprawa dostęu do zatrudnienia oraz wspieranie aktywności zawodowej $w$ regionie, $\mathrm{w}$ tym także projekty systemowe $\mathrm{w}$ ramach Poddziałania 6.1.3 Poprawa zdolności do zatrudnienia oraz podnoszenie poziomu aktywności zawodowej osób bezrobotnych;

- w ramach VI Priorytetu POKL, Działanie 6.2 Wsparcie oraz promocja przedsiębiorczości oraz samozatrudnienia;

- w ramach VIII Priorytetu POKL, Działanie 8.1 Rozwój pracowników i przedsiębiorstw w regionie.

Projekty te były realizowane przez powiatowe urzędy pracy w całej Polsce, natomiast nadzorowane były przez wojewódzkie urzędy pracy, które pełniły funkcje instytucji pośredniczących lub wdrażających. W ramach tych projektów były finansowane instrumenty rynku pracy i usługi rynku pracy wymieniane w Ustawie z dnia 29 kwietnia 2004 roku o promocji zatrudnienia i instytucjach rynku pracy (Dz.U. nr 69, poz. 415 z późn. zm.). Realizowane były w ramach tych projektów formy wsparcia, takie jak szkolenia, staże, wyposażenie lub doposażenie stanowisk pracy (Projekty systemowe...).

W ramach wdrażania powyższych działań i poddziałań urzędy pracy w poszczególnych województwach dysponowały znacznymi środkami. Dla przykładu, na wdrożenie powyższych działań i poddziałań, powierzonych do realizacji przez Samorząd Województwa Świętokrzyskiego w latach 2007-2013, Wojewódzki Urząd Pracy w Kielcach, pełniący funkcję instytucji pośredniczącej II stopnia, dysponował łączną kwotą 156369000 euro. Oferowano pomoc w bardzo szerokim zakresie. Wojewódzki Urząd Pracy w Kielcach informował, że kiedy w marcu 2010 roku ogłosił pierwsze konkursy naboru wniosków w ramach działań 6.1 Poprawa dostępu do zatrudnienia oraz wspieranie aktywności zawodowej w regionie, 6.2 Wsparcie oraz promocja przedsiębiorczości i samozatrudnienia oraz 8.1 Rozwój pracowników oraz przedsiębiorstw $w$ regionie, nie licząc projektów systemowych, realizowanych przez poszczególne powiatowe urzędy pracy w regionie, do kieleckiego WUP wpłynęło łącznie 451 wniosków. W tym okresie też wszystkie powiatowe urzędy pracy z regionu złożyły wnioski o dofinansowanie projektów systemowych reali- 
zowanych w ramach Poddziałania 6.1.3 Poprawa zdolności do zatrudnienia oraz podnoszenie poziomu aktywności zawodowej osób bezrobotnych. Na podstawie złożonych wniosków z powyższego poddziałania dyrektor Wojewódzkiego Urzędu Pracy w Kielcach podpisał ze wszystkimi powiatowymi urzędami pracy umowy na realizację projektów w trybie systemowym. Łączna wartość dofinansowania powyższych projektów ze środków POKL wyniosła 79696000 zł. Natomiast w ramach wyżej wspomnianych projektów konkursowych dyrektor WUP w Kielcach podpisał 130 umów na łączną kwotę dofinansowania 193178893 zł (Stan wdrażania działań realizowanych przez Wojewódzki Urząd Pracy w Kielcach w ramach Programu Operacyjnego Kapitał Ludzki).

\section{Przykład łódzkich urzędów pracy}

Podobne działania miały miejsce w ramach urzędów pracy na terenie Łodzi. Do końca 2011 roku w mieście zadania samorządu powiatowego, o których mowa w ustawie o promocji zatrudnienia i instytucjach rynku pracy (Dz.U. 2016 r. poz. 645 z późn. zm.) realizowały Powiatowy Urząd Pracy nr 1 (dalej PUP nr 1) w Lodzi oraz Powiatowy Urząd Pracy nr 2 (dalej PUP nr 2) w Łodzi. Z dniem 1.01.2012 roku powstał na terenie miasta jeden Powiatowy Urząd Pracy (dalej PUP), który przejął zadania i zobowiązania wspomnianych PUP nr 1 i PUP nr 2 w Łodzi.

W perspektywie finansowej Unii Europejskiej 2007-2013 urzędy pracy realizowały projekty systemowe w ramach Poddziałania 6.1.3 Programu Operacyjnego Kapitał Ludzki. Pierwsze umowy ramowe o dofinansowanie ze środków Unii Europejskiej projektów systemowych w perspektywie 2007-2013 podpisane zostały w 2008 roku przez PUP nr $1 \mathrm{w}$ Łodzi dla projektu Lódzki rynek pracy to Twoja przyszłość oraz przez PUP nr 2 w Lodzi dla projektu Wspieramy Twoja aktywność. W latach 2009-2014 podpisywane były aneksy do wspomnianej umowy ramowej. Konsekwencją połączenia urzędów w 2012 roku była równoległa realizacja przez PUP w Łodzi dwóch projektów pozakonkursowych w latach 2012-2014. W poszczególnych latach realizowane były zadania, o których mowa w Ustawie o promocji zatrudnienia i instytucjach rynku pracy.

W przypadku projektu Eódzki rynek pracy to Twoja przyszłość zadanie w formie refundacji pracodawcom kosztów wyposażenia lub doposażenia stanowisk pracy realizowane było w 2014 roku. 
Poniżej dane dotyczące jego wykonania:

1. Liczba przedsiębiorstw, które otrzymały pomoc publiczną w postaci refundacji kosztów wyposażenia/doposażenia stanowiska pracy - 90, w tym:

- mikroprzedsiębiorstwa - 72;

- małe przedsiębiorstwa - 17;

- średnie przedsiębiorstwa -1 .

2. Liczba utworzonych stanowisk pracy -117 .

3. Liczba zatrudnionych na utworzonych stanowiskach pracy -128 .

4. Wartość udzielonego wsparcia - 2467 399,99 zł (dokumentacja projektu Lódzki rynek pracy to Twoja przyszłość).

W przypadku projektu Wspieramy Twoja aktywność przedmiotowe zadanie realizowane było dwukrotnie, tj. w 2008 roku oraz w 2014 roku. Poniżej dane dotyczące jego realizacji w poszczególnych latach:

Rok 2008

1. Liczba przedsiębiorstw, które otrzymały pomoc publiczną w postaci refundacji kosztów wyposażenia/doposażenia stanowiska pracy - 41, w tym:

- mikroprzedsiębiorstwa-33;

- małe przedsiębiorstwa - 7;

- średnie przedsiębiorstwa -1 .

2. Liczba utworzonych stanowisk pracy -48 .

3. Liczba osób zatrudnionych na utworzonych stanowiskach pracy -48 .

4. Wartość udzielonego wsparcia - $672510,64 \mathrm{zł}$.

Rok 2014

1. Liczba przedsiębiorstw, które otrzymały pomoc publiczną w postaci refundacji kosztów wyposażenia/doposażenia stanowiska pracy - 60, w tym:

- mikroprzedsiębiorstwa - 44;

- małe przedsiębiorstwa - 14;

- średnie przedsiębiorstwa -2 .

2. Liczba utworzonych stanowisk pracy -79 .

3. Liczba osób zatrudnionych na utworzonych stanowiskach pracy -80 .

4. Wartość udzielonego wsparcia - 1683 623,96 zł (dokumentacja projektu Wspieramy Twoją aktywność). 


\section{Kwestia efektywności udzielanej pomocy}

Przytoczone powyżej wielkości i liczby świadczą o tym, że w Polsce, w okresie programowania 2007-2013, zostały uruchomione i przekazane przedsiębiorstwom, w tym przedsiębiorcom z sektora MŚP, olbrzymie środki, które w wielkiej mierze pochodziły z funduszy unijnych, w tym z Europejskiego Funduszu Rozwoju Regionalnego oraz z Europejskiego Funduszu Społecznego. Środki w tym okresie programowania zostały przekazane i wyczerpane. Wszystkie sprawozdania mówią także, że zostały one przekazane przedsiębiorstwom, w tym także sektorowi MŚP, zgodnie ze wszelkimi wymaganymi procedurami. Jak widać z powyższego, pomoc publiczna każdego rodzaju, udzielana przez wiele instytucji, w tym także przez urzędy pracy, posiadała odpowiednie ramy instytucjonalne, które umożliwiły jej udzielanie. W przypadku pomocy publicznej udzielanej przez urzędy pracy były to urzędy pracy zarówno na poziomie powiatowym, jak i na poziomie wojewódzkim. Urzędy te, zarówno w Łodzi, jak i w całym kraju, podobnie jak inne instytucje, dysponują szczegółową sprawozdawczością na temat zgodności procedur oraz wydatkowania tych środków zgodnie z nimi. Dlatego też przyjmuje się powszechnie, że środki te zostały przez przedsiębiorstwa zagospodarowane lege artis. Natomiast zasadniczym pytaniem, które rodzi się w związku z udzielaną pomocą i transferem dużych środków publicznych, jest pytanie o trwalsze efekty i korzyści, które te transfery przynoszą. To zagadnienie, po kilku latach wydawania powyżej opisanych poważnych środków, należy zbadać. Sądzi się, że należy je przedstawić w taki sposób, aby odpowiedzi nie odnosiły się tylko i wyłącznie do kolejnego pokazania prawidłowości zastosowanych procedur. Tematem do szerszych badań jest kwestia długofalowych, trwałych efektów wydawania tego typu środków, tak aby uniknąć ewentualnych zarzutów odnoszących się, dla przykładu, do ewentualnej mislokacji tego typu środków. Dlatego też stwierdzenie, że środki te zostały wydane lege artis, nie zamyka dyskusji związanej z kwestią ich wydawania. Bardziej otwiera kwestię dyskusji naukowej na temat, czy środki te zostały wydane tak, aby przyniosły długofalowe, trwałe efekty. Pozostaje to otwartym pytaniem badawczym. 


\section{Podsumowanie}

Od 2015 roku w Unii Europejskiej okres programowania 2007-2013 uznaje się za zakończony. W okresie tym, w ramach pomocy publicznej, w tym także dostępnej w strukturze urzędów pracy, przekazano przedsiębiorstwom w Polsce, w dużej mierze z sektora MŚP, znaczne środki. Środki te udało się wydać zgodnie z procedurą oraz zgodnie z przewidywaniami. Jest to widoczne we wszystkich dokumentach poszczególnych instytucji, które powyższą pomocą się zajmowały. Dokumentacja ta potwierdza tezę, iż środki te zostały rozdysponowane zgodnie z przyjętymi wymogami formalnymi. Również w odniesieniu do sektora MŚP, który korzystał ze wsparcia urzędów pracy, w tym łódzkich urzędów pracy, można stwierdzić, że środki te zostały wydane lege artis i odpowiednio przez przedsiębiorców zagospodarowane. Natomiast ciągle otwartą kwestią badawczą pozostaje pytanie dotyczące długotrwałej efektywności udzielonej pomocy oraz jej wpływu na podniesienie konkurencyjności polskiego sektora MŚP.

\section{Literatura}

Dokumentacja projektów Wspieramy Twoja aktywność oraz Łódzki rynek pracy to Twoja przyszłość. Powiatowy Urząd Pracy w Łodzi, 93-121 Łódź, ul. Milionowa 91.

Instrukcja wypełniania wniosku o dofinansowanie projektu z Europejskiego Funduszu Rozwoju Regionalnego w ramach Regionalnego Programu Operacyjnego Województwa Łódzkiego na lata 2014-2020, s. 12. Pobrano z: www.rpo.lodzkie.pl (10.05.2017).

Projekty systemowe powiatowych urzędów pracy w ramach Programu Operacyjnego Kapitał Ludzki, s. 2. Pobrano z: www.pokl.gov.pl (3.06.2017).

Raport o pomocy de minimis w Polsce udzielonej przedsiębiorcom w 2015 r. Pobrano z: www.uokik.gov.pl (15.05.2017).

Raport o pomocy publicznej w Polsce udzielonej przedsiębiorcom w 2015 r., s. 9. Pobrano z: www.uokik.gov.pl (5.06.2017).

Stan wdrażania działań realizowanych przez Wojewódzki Urząd Pracy w Kielcach w ramach Programu Operacyjnego Kapitał Ludzki. Pobrano z: www.wup.kielce.pl (28.05.2017).

Wersja skonsolidowana Traktatu o Unii Europejskiej, Dz. Urz. UE C 202 z 7.06. 2016. 


\title{
THE STATE AID FOR SME SECTOR FROM EU FUNDS GRANTED BY LABOUR OFFICES - CASE OF LABOUR OFFICES IN LODZ
}

\begin{abstract}
SME sector is a very important actor for Polish economy. During the 2007-2013 programming, for the Polish enterprises, including the SME sector, the huge state aid was granted. It was granted by several Polish institutions, such a voivodships and local Labour Offices. Since 2015 year, the evaluation of that state aid is leading. Drawing up learn us about leading that grands with the law agreement. But it is impossibible to let them know about the long therm effectiveness of that aid. In that article that kinds of state aid are shown and the opening research question is the problem of effectiveness of that aid.
\end{abstract}

Keywords: staid aid, EU funds, public institutions, SME sector

Translated by Eugeniusz Brzuska

JEL code: E66 